\title{
The Seventh Seal on the Czech Stage
}

\section{Eva Stehlíková}

\begin{abstract}
Whatever might be the reason for the theatre taking so much inspiration from film in the 21st century, the fact remains that the work of Ingmar Bergman is inspiring for theatre-makers all over the world. In this article, I briefly focus on three Czech productions of The Seventh Seal; namely a performance by the students of the Prague Conservatory which was put on under the title Wood Painting in 1995; a production by the independent student group Oldstars of 2011 and finally the only production on a professional stage, in the National Theatre in Brno in 2013, which is also recorded in the Swedish database. ${ }^{1}$ I also draw the reader's attention to special productions inspired by some motifs of Bergman's Seventh Seal. These, however, set the story in the present (In a Dark House in the Middle of the Night in 2006) from the now defunct Seven and a Half Theatre (Divadlo Sedm a pull), and Persons produced by the Theatre on the Balustrade in 2018.
\end{abstract}

\section{Keywords}

Ingmar Bergman, film adaptation, theatre adaptation, Czech theatre

1 As reported on the website http://www.ingmarbergman.se/en/productions. In the Czech Republic this phenomenon was already discussed (ČERNÍK 2013); the findings can be summarized as follows:

Scenes from a Marriage - Divadlo na Vinohradech (Vinohrady Theatre) in 1998-2007, Dejvické divadlo (Dejvice Theatre in 2003 - the Swedish inventory incorrectly lists it as The Spejbl and Hurvínek Theatre), Městské divadlo Mladá Boleslav (Municipal theatre Mladá Boleslav) in 2008;

After the Rehearsal - Národní divadlo Praha (the National Theatre Prague) in 1998, Divadlo U stolu (At the Table Theatre) Brno in 2010, Divadlo v Řeznické (the Theatre in Řeznická) Prague in 2011;

Autumn Sonata - the Studio Dva (Two Studio) at the Theatre on the Balustrade in 2003, the Paradox Studio, Brno in 2017;

Sarabanda - Divadlo Na zábradli (the Theatre on the Balustrade) in 2008,

Cries and Whispers - a ballet at the Dance Centre of Charles University in 1998, Disk (Disk Theatre), Prague 2018, Persona - Duncan Centre Prague in 2011, Summer with Monika - Divadlo Kolowrat 2018 


\section{From the play, Wood Painting to the film, The Seventh Seal}

The Seventh Seal (1957) is a film adaptation of Bergman's one-act play Wood Painting (1954). Wood Painting was broadcast as a radio play by Swedish Radio in the same year it was written. ${ }^{2}$ It was produced twice in as a theatrical performance in Swedish theatres a year later. The first production at the Malmö City Theatre in March 1955 was directed by Bergman himself and ran for 18 performances, the other at the Royal Dramatic Theatre by Bengt Ekerot, who portrayed the character of Death in the film The Seventh Seal (16 ${ }^{\text {th }}$ September 1955, 18 reprises too) (STEENE 2005: 572-4).

The text ${ }^{3}$ was translated into a number of languages, including Danish, English, French, Spanish, Polish as well as Czech. ${ }^{4}$ In the note to the Czech translation (and adaptation) by P. Ochová and B. Sobotka from 1966, the translators state that this is the same translation broadcast by Czech Radio ${ }^{5}$ at the end of the year adding that for Bergman the play had become the starting point for the film The Seventh Seal, "which is coming to our cinemas this autumn'. This happened in 1967. However, the film story The Seventh Seal was published in Czechoslovakia as late as $1988 .{ }^{6}$ Only then had Czech readers and audiences everything at their disposal that allowed them to follow the gradual formation of the story as well as the main propositions of the film.

The one-act play Wood Painting is usually viewed as preparation for The Seventh Seal (DONNER 1965). ${ }^{7}$ The author himself contributed to this view by opening the play with the Narrator describing paintings in a small wooden church in Småland. ${ }^{8}$ The idea to write Wood Painting occurred to the artist when teaching at a school in Malmö when he needed a play for his students and recalled an old experience of his. He then decided to use this theme for the film The Seventh Seal (BERGMAN 1987: 272).

2 Trämálning. Moralitet av Ingmar Bergman (Wood Painting. Morality play by I. B). In Svenska radiopjäser. Stockholm: Sveriges Radios förlag and Bonniers Ugglebocker, 1954: 9-61. With a brief prefatory note and introducing the author as a director and writer (STEENE 2005: 88).

3 Trämálning - enaktare för amatörer (Wood Painting - a one-act play for amateur actors). Stockholm: Albert Bonniers, 1956.

4 Wood Painting. Repertoár Malé scény (The Small Stage repertoire) of 1966, 11: 8-22; new translation by Z. Černík: After the Rehearsal, the programme of the performance in National theatre Prague 1998, 40-54. Not recorded by (STEENE 2005).

5 The first radio adaptation on Czechoslovakia II station, on 29th October 1966 was unfortunately deleted (directed by Josef Henke), the other on the Czech Radio station Vltava in 2005 (directed by Vlado Russia) - see (HANÁC̆KOVÁ - BOJDA).

6 According to (STEENE 2005: 91) Sjunde inseglet (The Seventh Seal). Film script. Unpublished Script II, dated 5 June 1956 and dedicated to Bibi Anderson, 128 pp, Script II was adapted as a serialized novella in Allere 84, no 14, through 18 (1960), but has never been published in its entirety in Swedish. Script II has appeared in numerous translations. See (BERGMAN 1988).

7 The first Czech translation of Wood Painting from 1966 supports this view as it is accompanied with photographs from The Seventh Seal which do not correspond with the text of the play - e.g. there is the comedian Jof, Mia's husband, who does not appear in the original play at all.

8 Similarly, sometime later Bergman writes about his experience of seeing medieval church paintings when travelling in Sweden with his father (OLIVA 1966: 91-92), which he also repeats in Laterna Magica (BERGMAN 1987: 271). 
The evident closeness of these works begs for them to be compared. Necessarily, this entails small but significant inaccuracies. So, Steene argues that:

The main difference between stage version and the screenplay is that in the original play, Death is not a dramatic character but performs the role of narrator. Squire Jöns' part is more central in the play while the Knight's role is almost mute. In the play, Maria (Mia) is more explicitly cast as Virgin Mary while Jof, Mia's husband in the film, is absent. The Witch has a more pronounced and active role in the stage version. (STEENE 2005: 571)

In no way does it follow from the text of the play that the Narrator is identical with Death nor does Death appear as a dramatic character there. On the contrary: Death under the name Stern Lord (or the Sternest Lord) who all characters wait for, concludes the play and is also given the opportunity to say the credo, namely that in the darkness, in which people live, they would not find anyone to hear their grievances and be moved by their suffering.

The role of the Narrator is simple: he brings characters to life based on the images decorating the church and the help of other characters. The number of situations and the number of persons was apparently given by the fact that Bergman had to come up with a role for each of his students. The future central figures of The Seventh Seal the Knight and his Squire already get contours; however, they are not yet sufficiently shaped. The Squire is jovial and takes pleasure in chatting with other characters, whether a young witch Tyan or Blacksmith whose wife has run off. He is an agnostic: believing only in himself. But even the dreadful experience of a crusade to the Holy Land did not make him lose compassion as he is willing to share his last slice of bread. It is only at the end of the play that the Knight, somewhat in the background (he was probably supposed to be even mute because the Saracens had deprived him of his tongue $)^{9}$ confides in the Stern Master with his faith and doubts, asks for a postponement as he must find God before his death. He even protests which is the attitude taken on by the Squire as the theme develops further; being able 'to roll his eyes and move his toes' the Squire experiences the end of life as an unheard-of victory. The search for God, a certain conciliatory attitude of the Knight and defiant lack of humility on the part of the Squire who refuses to deal with anything outside his practical experience, are merely two sides of the same coin. Together, both of them embody a Bergmanian Everyman who meets Death halfway through life. This is a theme Bergman was very familiar with. ${ }^{10}$

It stands to reason that as the images of Wood Painting gradually become individual stops on Everyman's journey, in the film some characters must be suppressed either because their opposition seems too abstract (the young witch and Mary with the infant) or useless (the girl telling pilgrims about the plague at the beginning and taking characters to see the Sternest Lord is later omitted). On the other hand, the group of actors is

9 See (BERGMAN 1991: 272).

10 Commenting on his own play Death of Punch of 1942, he said it was 'a shameless plagiarism of Casper's Shrove Tuesday by August Strinberg and Everyman by Hofmannsthal' (BERGMAN 1987: 143). 
strengthened here as Jof and Mia with their infant son join them. In Bergman's morality play, the Knight does not meet his Kindred or Good Deeds, nor personifications such as Beauty, Strength or Discretion but characters, each of which represents some aspect of a human being - greed, lust, selfishness, patience, tenderness, generosity (KALIN 2007: 83). The Knight, seeking to obtain a postponement, is not guided by the fear of a sudden end, but by an anxious sense of an unfulfilled knowledge of life (CIESLAR 1982: 406). The only one begging for the postponement in Everyman's manner is the unprincipled actor Skat. ${ }^{11}$ The character of Death undergoes a great transformation: from a rather abstract character of the Sternest Lord he gradually acquires a specific, however a somewhat androgynous mask due to his white makeup. He also has surprising new features: he is cunning (extracting information from the Knight on his chess strategy), yet he is not omniscient (the Knight can fool him) and has no secrets.

\section{Czech theatrical interpretations of The Seventh Seal}

\subsection{Wood Painting in 1995}

Surprisingly, the first Czech adaptation of The Seventh Seal was performed under the title of Wood Painting. The script was prepared for the second-year students of the Prague Conservatory (DIK) by Vlasta Krautmanová in 1995. It is unclear as to why this title was chosen, nevertheless it is evident from the preserved video recording ${ }^{12}$ that the adaptation was inspired by the movie The Seventh Seal. ${ }^{13}$ Overall, it follows the story as we know it, with some occasional individual motifs being rearranged, some characters being omitted and some scenes being put in a different place in the storyline (e.g. Jöns rescues the girl from a monk before the Knight enters the church).

More important, however, is the overall setting of the story which begins at the Knight's castle. The Knight's wedding to Karin is just taking place there. The young couple is married by a fanatical monk (Raval in Bergman's story) who sends the Knight out on a crusade at the same time. His place in the story is thus emphasised. We are yet to meet him as a monk steeling from those killed off by the plague, it is also probably him torturing a young witch, he helps villagers to vilify the actor Jof and finally, when dying he creeps up to the group which runs away from the plague led by the Knight and Jöns. He epitomizes negative forces within the story. On the other side of an im-

11 In a short dialogue Skat gets typical responses, through which medieval death communicates with Everyman (I have a performance - It is cancelled; My contract... - Your contract is terminated; My children, my family... - They can do without you).

12 Video recording is available at the Theatre Institute under no 5436. Further information: directed by Peter Palouš; scenography and costumes by Milan Čech; music by Milan Jíra; choreography by Ivan Krob; dramaturgy by Vlasta Krautmanová.

13 Jiří Osvald is usually stated as the author of the translation. According to the publication Zamlčovani prekladatelé: bibliografie 1948-1989 [Concealed Translators - Bibliography 1948-1989. Prague: The Czech Literary Translators' Guild] Josef Vohryzek was the actual translator, not Jiří Osvald. 
aginary axis are actors Jof and his wife, Mia, whose status is still reinforced by the fact that Mia is pregnant. The overall tone of the story is rather positive: The Knight has transformed the obtained postponement in the best possible way because he did not think of himself and helped the young couple to flee from Death. The final birth of the child then becomes a symbol of a new life that even conquers the plague.

A group of young actors (aged about twenty) is supplemented by extras made up by the youngest students who embody wedding guests, plague victims, flagellants, audience of the actors' performance and inn guests. Obviously, the director thought that the actors should be given a chance within the production to develop the theme of their characters in accordance with their psychophysical abilities. This led to a natural stylisation - they were all young. The simple stage design is playful. It worked only with wood serving in the form of sheets as the entrance to the stage, as the door to the church or a table in the inn, and in the form of wooden blocks it changes into seats or a tree which is being felled by Death. At the centre of the scene there is an outline of an actors' carriage on which theatre performances are staged. Costumes confined to the common stylisation of the Middle Ages (including the skeleton, which Skat has on black leotards under his colour coat) are easy enough for the audience to read. The space of the play is wittily extended by sounds - sea surf, the sound of bells or the singing of birds.

\subsection{The Seventh Seal in 2011}

An independent student group Oldstars working in the Žižkov neighbourhood of Prague studied their "minimalist staging about the meaning and the end of the world based on the renowned film story by Ingmar Bergman The Seventh Seal' ${ }^{14}$ for the space of the then basement club. However, it was originally meant to be performed in the romantic ruins of the Gothic castle Helfenburg near Bavorov. The young actors stayed there for one week preparing the production which premiered on $30^{\text {th }}$ June 2011, and which was later successfully staged at the Theatre in Celetná on $24^{\text {th }}$ February 2012. In addition to photographs in the archive of the Oldstars group,,$^{15}$ and a short sequence on Youtube (the Knight meeting Death, the game of chess and Jöns asking the way), ${ }^{16}$ there is also a trailer. ${ }^{17}$ Otherwise, we only have to rely on oral history and memories of the director Zuzana Malá.

The group used the film story for the script, however, they did not draw much inspiration from the film visually as evidenced by the scenography among other things. This is minimalist but also changing, always adapted to the space where it was staged. A rope

14 The productions was staged as defined by the exemption of the Copyright Act pursuant to § 35, Act No

121/2000 Coll. Further information: direction and adaptation by Zuzana Malá-Horáková.

15 Available online at http://oldstars.cz/index.php/photo/album/sedmapecet.

16 Available online at https://www.youtube.com/watch?v=oe9KbxNCALU.

17 Available online at https://www.youtube.com/watch?v=OjScrDbvMCo. 
Eva Stehlíková

The Seventh Seal on the Czech Stage
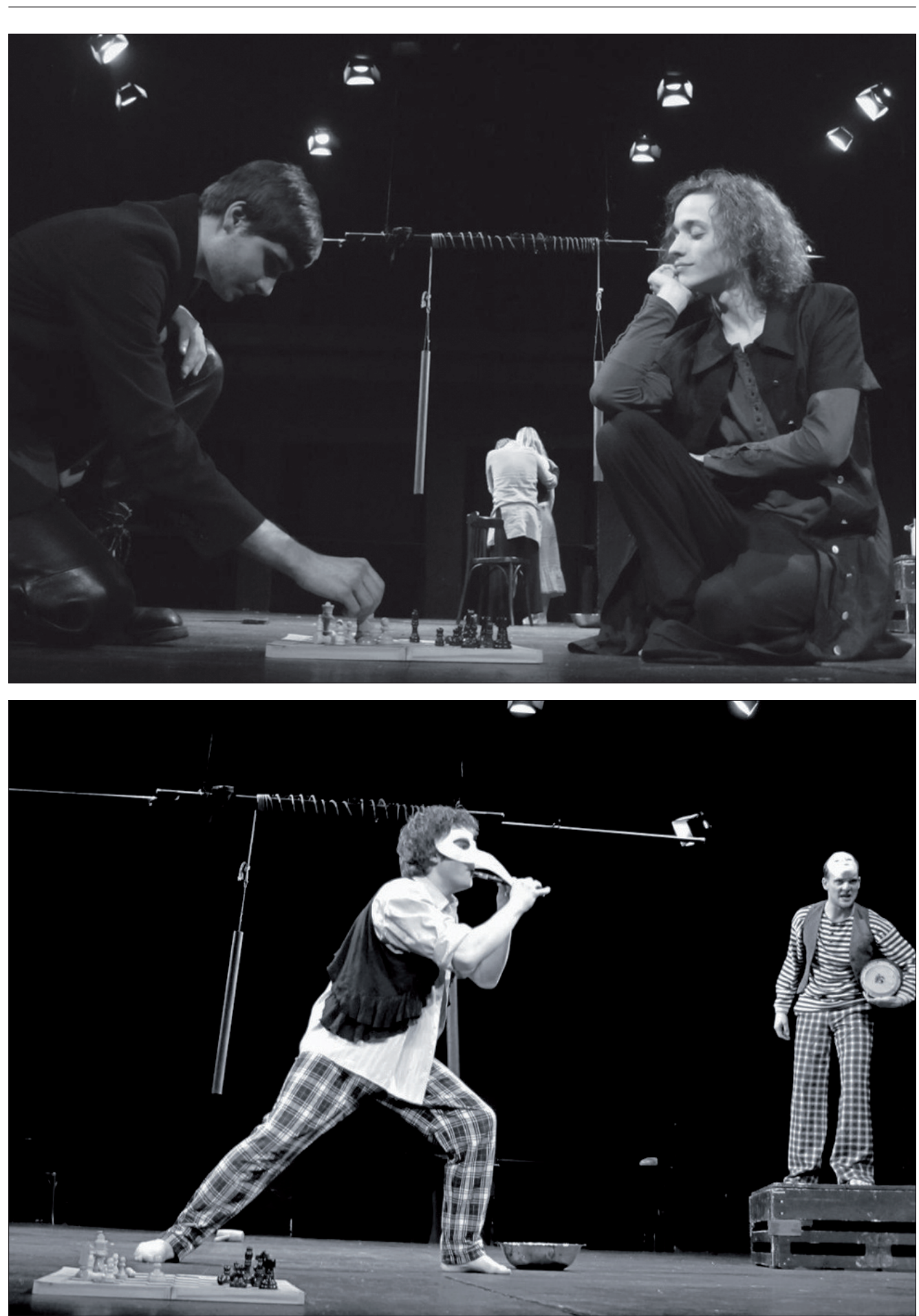

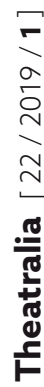

Fig. 1a-b: The Seventh Seal. Oldstars. 2011, Archiv Oldstars. 


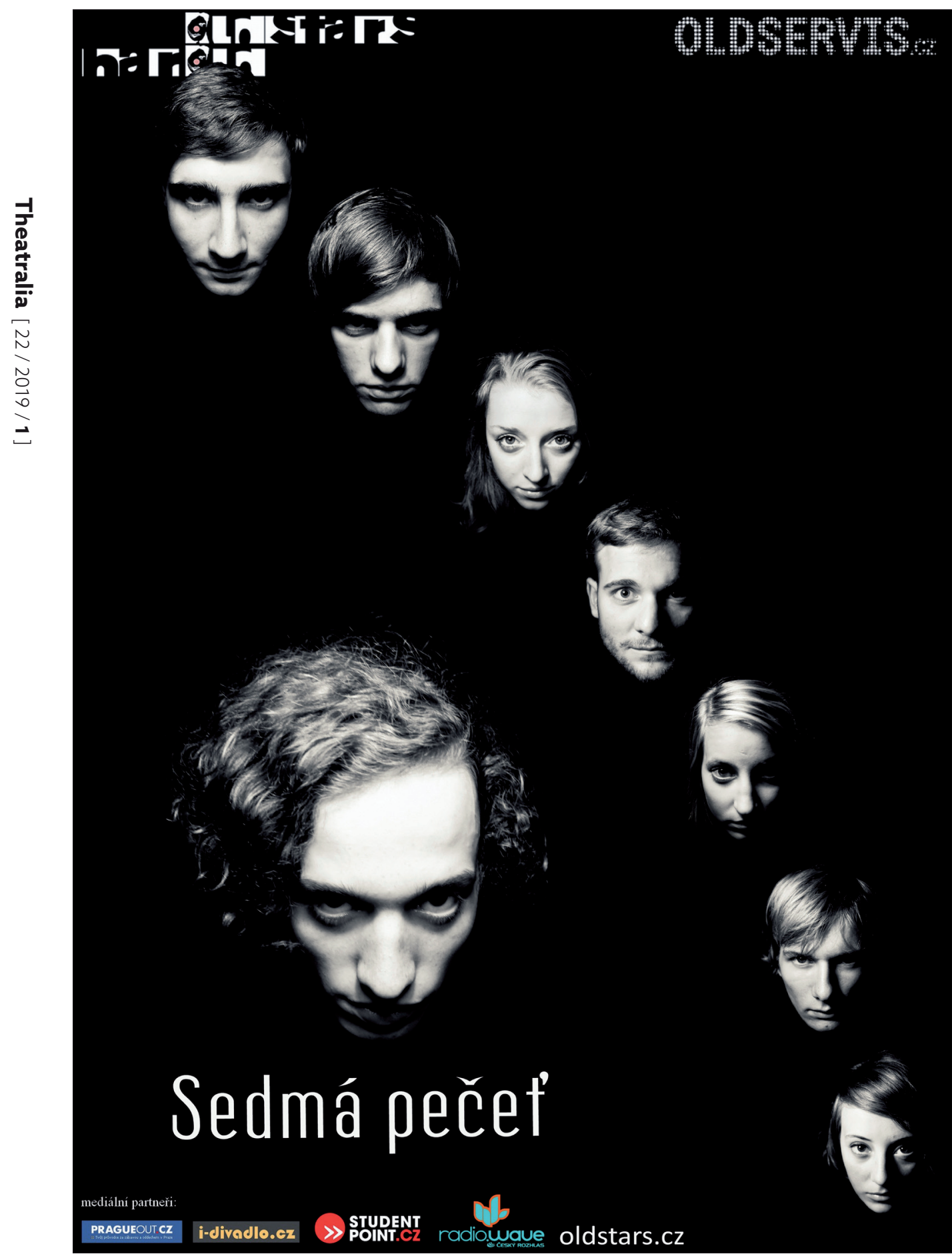

Fig. 2: Poster of the The Seventh Seal. Oldstars. 2011, Archiv Oldstars. 
was enough on which Skat hung as if on a tree, on which the painter climbed while describing paintings in the church and which Mia used to rock her baby. The rope also served as a pillory for the witch. Even the famous Dance of Death which concludes the film was not staged.

In an exceptional way, the theatre world was linked to Death that "played different roles for the Knight, as if staging the world for him and let the Knight recognize him in the form of a dead body lying by the road, the monk accompanying flagellants as well as the witch, confessor, Raval' (MALÁ-HORÁKOVÁ 2018). They took advantage of the fact that it was possible to link the natural (actually realistically conceived) world of actors with their stylized speech in theatre performances, which culminates in the character of Jof being able to go beyond reality in his insightful visions.

Their view of the state of the world is not bleak: Antonius Block accepts a meeting with Death as a challenge in which he succeeds in the end as he obtains time and turns it to good use. Returning home, he ceases to dwell on himself focusing his attention to the people around him (on a simple family of actors allowing them to escape from Death, on a young witch whom together with Jöns he helps to soothe her suffering). Becoming aware of his death, he accepts it. Their Apocalypse is not just about the transience of earthly life and a confrontation with destruction but 'at the same time it opens up space for belief that there is still a mysterious incentive, meaning, order and good beyond it' (MALÁ-HORÁKOVÁ 2018).

\subsection{The Seventh Seal in 2013}

The only professional theatre to stage a theatre adaptation of The Seventh Seal so far is the National Theatre in Brno. ${ }^{18}$ It invited (in a difficult time of its artistic crisis) opera director Josef Nekvasil ${ }^{19}$ and stage designer Daniel Dvořák to work on this production. From the outset they set the horizon of their spectators' expectations by engaging two artists whose work was well known.

As usual, Daniel Dvořák filled the whole stage. A lot of projecting takes place here (the sea, clouds, a cross, skeletons made out in an abstract way resembling paintings in

18 A video recording of the production is owned by the Theatre Institute under no 14995 as well as by the Archive of the National Theatre Brno. Further information: Adaptation using the translation of Jiři Osvald (recte Josef Vohryzek), Jiří Nekvasil, director Jiří Nekvasil; stage: Daniel Dvořák; costumes: Marta Rozkopfová; music: David Smečka.

19 The Seventh Seal previously captured Jiří Nekvasil's attention. During his studies together with Vladimír Wimmer he planned to create a short film opera on the theme of The Seventh Seal, however, they carried it out later as The Knight and Death (performed by National theatre at the Prague State Opera in 2001). Composer: Vladimír Wimmer, libretto Alexej Fried Jr. Opera opened the project Pounding on the Iron Curtain aimed at establishing a platform for the launching of opera premieres by contemporary composers in productions of young artists. The story of the fifteen minutes opera 'takes place on two levels. One is the ordinary today's world into which through a dream of the main character Jof the theme of a medieval knight playing chess game with Death for his life is transferred, even when he knows he has no chance to win. However, his young girlfriend Mia fails to take the description of the dream seriously' (BALCÁRKOVÁ 2007: 27). 


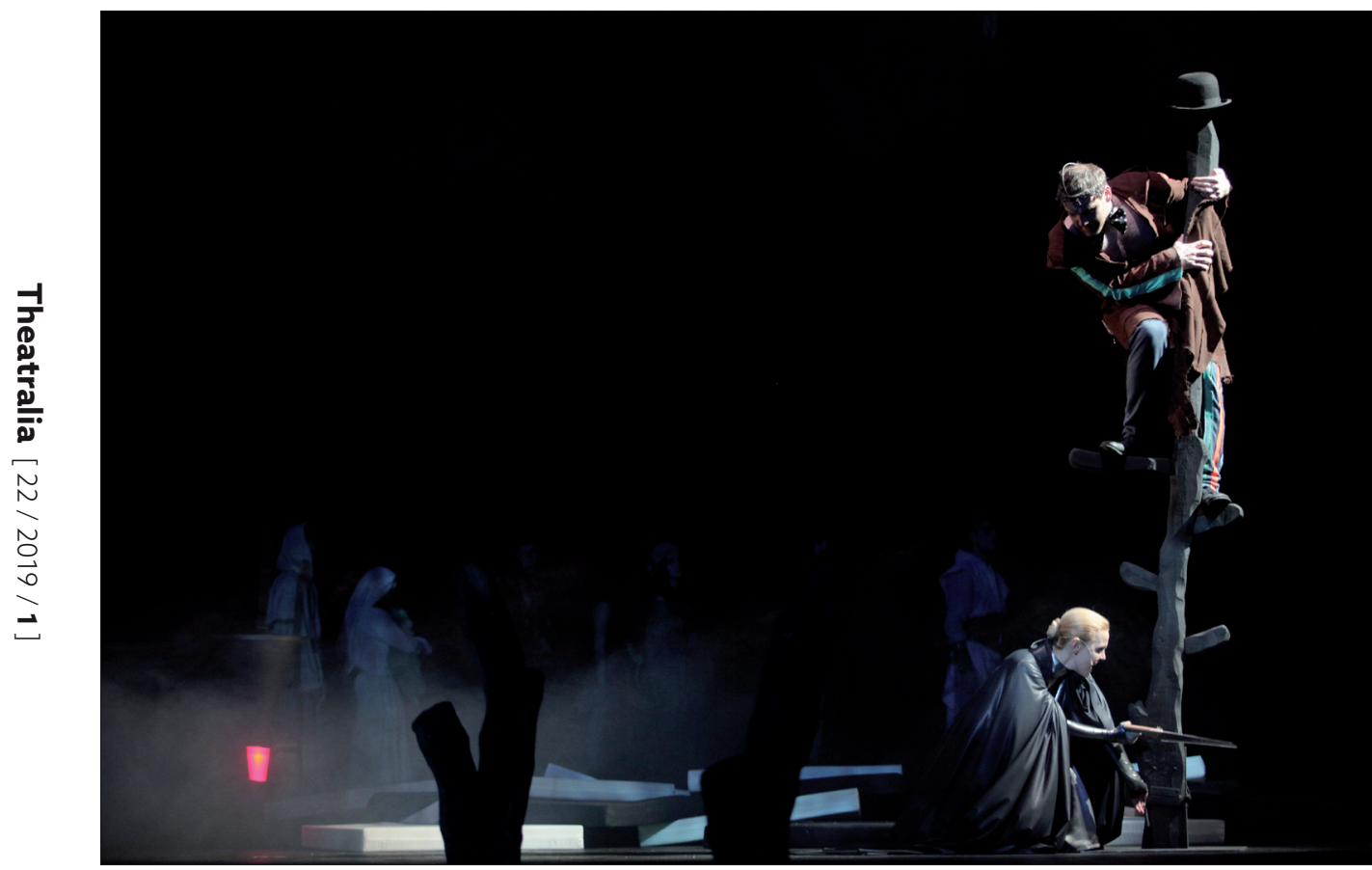

Fig. 3: The Seventh Seal. National Theatre in Brno. 2013, Archiv NDB.

a church), the proscenium is used as well (bones of plague victims are piled up there) and characters penetrate into the audience (they exit through a passage and acting takes place in the box, too). The whole space is dominated by a pendulum with a shining point which measures human time all the time.

Scenography as well as direction was more reminiscent of works of opera or musicals. This is also encouraged by a nonsensical use of wireless microphones, attempts at singing and, after all, the costumes (clean and ironed costume of the Knight returning from the tumult of war, Star Trek like costume of Death). The director leads the story on the very edge of situations shown in a realistic way (the alleged tortured witch is painted with theatrical blood) and a sort of entirely abstract actions: at the beginning a chessboard falls from above with a large clatter which remains on the stage throughout the play. The main protagonists are said to play chess several times, however, nobody gets near the chessboard.

The director retains the sequence of scenes and dialogues. The figure of Death was the only one to undergo a transformation. Death is not a man, but a young woman in line with the Czech tradition, ${ }^{20}$ moreover, a beautiful one, covering who covers her

20 Death is in the feminine gender in Czech and is mainly found in the female form in fairy tales as Death - Fairy Godmother. It follows that in the Czech translation of Wood Painting or The Seventh Seal that Sternest Lord should have a feminine form. However, in a famous and award winning Czech film (Dařbuján and Pandrhola, directed by Martin Frič, 1959) Death takes the form of a man - the Reaper. 
Eva Stehlíková

The Seventh Seal on the Czech Stage

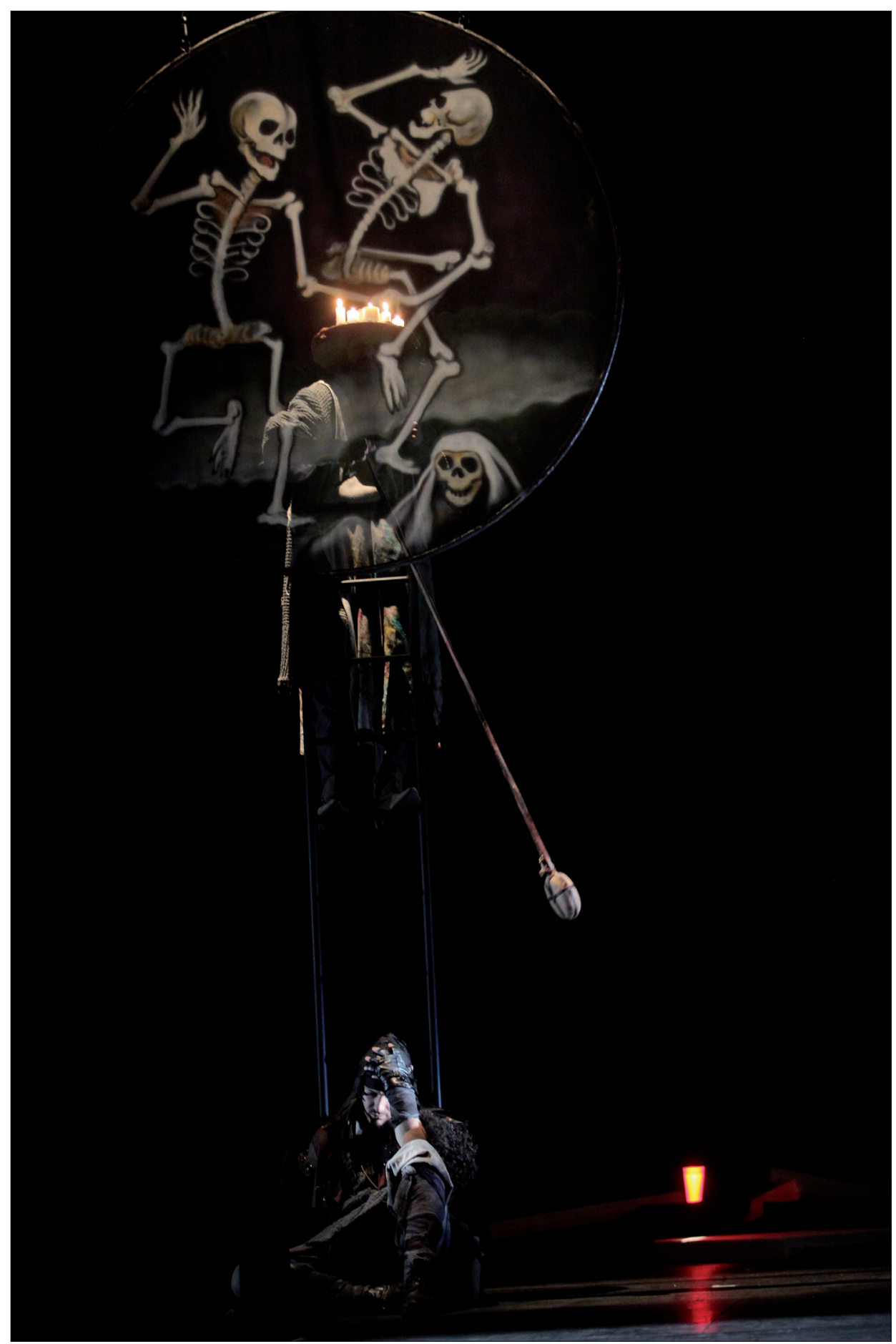

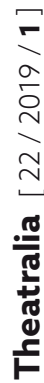

Fig. 2: The Seventh Seal. National Theatre in Brno. 2013, Archiv NDB. 
face with a mask only at the end of the play. Even the friendliest review states that 'the desired effect is somewhat spoilt by the fact that Death is a pretty blonde. Not only that the audience is not afraid of her; it may even come to the conclusion that playing chess with such a creature may be quite pleasant. The scary emptiness under Ekerot's androgynous mask is gone' (ČERNÍK 2013).

\section{On the issue of theatrical adaptations}

The proximity of the theatre and film has been clear ever since the beginnings of film. One could say (in a schematic fashion) that it has gone through at least three basic stages. In the first stage, film benefited from the theatre and literature in a brazen way (after all, drama itself was classed as literature) in accepting popular stories and getting inspiration from its methods. In the second stage, as film developed its own specific language, the cards were turned. The theatre (especially avant-garde theatre) took over film principles (editing, montage, shortcuts etc) and technical resources (projections). In Czechoslovakia, this phase culminated in Radok and Svoboda's Laterna magika multimedia project (which came to fame in the European context at the 1958 Brussels Expo). In the third stage, launched in full force in this country in the $1990 \mathrm{~s}$, the theatre drew from familiar film works, staged their stories and followed their scripts.

The frequency of such theatrical adaptations is increasing. One of the reasons is purely pragmatic. The theatre relies on the fact that well-known, successful and popular film stories will attract audiences. No wonder, then, that successful Czech films of the 1940 s, 1960s and 1970s are recycled. But stage directors also look for strong themes, going beyond 'mere fun' and therefore take hold of works by non-conformist directors. Among the popular ones on Czech stage are Federico Fellini (81/2, La Dolce Vita, La strada, Orchestra Rehearsal), among the younger ones there are Lars von Trier (Breaking the Waves, The Idiots, Dogville) and Pedro Almodóvar (Women on the Verge of a Nervous Breakdown). However, this trend is not always received positively. ${ }^{21}$

Adaptation of film stories into a theatrical form is a complex process. Although seemingly just about transferring the story from one performative medium into another (which is Showing - Showing, as Linda Hutcheon would say), it always means transcoding from the language of film to the specific language of theatre. It can be a source of dissatisfaction for audiences who measure a theatre performance with their memories of the film. So, it happens that a certain advantage of such an adaptation based on the inherent knowledge of the original story (i.e. a kind of pre-established state known from works dealing with mythological themes) proves to be disadvantageous.

21 See (VEDRAL 2012): 'The moment the theatre recycles media contents and mass media shapes so as to meet viewers' expectations of standards derived from these media but not from itself, it becomes a tamed part of the global mediocracy, thus resigning its original purpose, expressed, for example, in Hamlet's monologue to actors.' 
Bergman directly refused to give consent for his films to be used as the basis for adaptation. Bergman's Foundation, which has assumed the performing rights, is more benevolent, however, it 'checks' new productions. ${ }^{22}$ The question arises here as to what extent stage directors can step outside Bergman's shadow. There is, however, a fundamental difference between adaptations of Bergman's scripts focusing on partnerships and the adaptation of The Seventh Seal. Screenplays essentially embodying the world in a realistic way can be treated in a stylised fashion. However, The Seventh Seal - dealing in the manner of medieval moralities with basic questions of the meaning of life and death in easily deciphered symbols - can be hardly be told in a different mode in theatre.

Although all interpreters of The Seventh Seal (be it the film or the film story) will probably agree that Bergman's God does not respond, the interpretations of this work may still differ from one another. There may be significantly different interpretations of some of the characters; Jöns, for example, can be seen as a cynical individual (KALIN 2007: 82) or a wise ironist. Either way, he is regarded by Cieslar as one of the finest Bergman's characters (CIESLAR 1982: 406). In the same way the overall evaluation of the film may range from a hint of spiritual atonement to a bitter and depressing image full of dread of the plague of the 1950s, the nuclear apocalypse (AMALVI 2002: 747). This confirms the fact that any theatrical production is not necessarily just a reproduction, but they may be open to a different tone, closer to heart of new producers. However, this depends, in my opinion, on whether stage directors are able to break away from the film they are adapting and deliver the topic in the first place - as Oldstars managed to do. Excessive reverence and dependence on film image is counterproductive.

The confusion over the production by National Theatre in Brno where reviews were at odds with a rather friendly response by the audience takes us back to the 'pre-established' state. From Internet discussions within the younger generation ${ }^{23}$, it is clear that most of the contributors have never seen Bergman's film (with older viewers labelling it as a cult movie). They just appreciated the fact that the theatre flooded with glossy repertoire had put on a demanding piece. It was not the production itself but the Bergmanian theme that was received so positively.

The admiration for Bergman's work was only one of the reasons for the theatre adaptation of The Seventh Seal. There is another factor, a specific Czech one: for decades the Communist ideology made death taboo, driving it out of arts and passing an absurd slogan about it: Life may die but death must not live. It became something almost unseemly for an individual to meet his death and formulate crucial questions such as: where do we come from? or where are we going? I find it significant that it was the youngest theatrical generation not fully affected by Communist propaganda to confront this theme head on. Both Prague Conservatory students as well as members of the Oldstars group, themselves graduates of arts schools and the renowned radio children's studio, accepted Bergmanian Death unchallenged, inclining towards its androgy-

22 See http://www.ingmarbergman.se/en/ingmar-bergman-foundation.

23 Available online at https://www.i-divadlo.cz/divadlo/narodni-divadlo-brno/sedma-pecet. 
nous form but above all seeking a way of understanding it and reconciling themselves with it. In contrast, Death in the performance of the National Theatre in Brno in the form of a pretty blonde shows that the artists there converted its image into exciting attractiveness of current musical productions without asking any questions regarding its role. Nevertheless, both youthful productions, performed in a highly professional way, exceeded the quality of standard professional productions of that time.

When the now defunct Seven and a Half Theatre became inspired in 2006 by some of Bergman's scripts to produce a new performance, calling it In a Dark House in the Middle of the Night, it was suspected of using this title due to the theatre's inability to resolve copyright issues. Although the theatre became infamous for neglecting to follow rules of any kind, ${ }^{24}$ it seems there was something different at stake here. The director M. T. Růžička and his dramaturg S. Polanská did not adapt particular Bergman's plays, but they used individual situations and motifs to create a multi-layered performance where all story lines were linked by the character of Ingmar Bergman. Bergman featured here as a director writing a script for his acting company. Out of the interwoven stories there came to the foreground the theme of the wandering Antonio Block playing chess with Death (which is a motif from The Seventh Seal) and Bergman's failing relationship with Liv Ullman (known well enough from his stormy life). As a dialogue, this was based on the text between the spouses Johan and Marianne from the film Scenes from a Marriage. It was charming that Liv and Death were embodied by the same actress (KRYŠTOFOVÁ 2009: 82). One can thus say that an entirely new and different text was created here bearing strong traces of activities by other creators. The Seven and a Half Theatre produced the work of a number of artists and from its inception the repertoire consisted mainly of dramatization or adaptation of literary or cinematographic works. This meant that new and untried scripts were introduced. Thus, it differed in a positive way from established theatres which flooded the stage with moneymaking musicals and established classic works expected to bring success.

This was the course mainly followed by small, amateur or semi-professional theatres. The titles used or the ostentatious presence of the translator's name or the names of those who have adapted the script always bear witness to an active attitude to the text. Bergman's text may be the point of departure here; nevertheless, his text has lost its dominant status. New texts are added to it which serve as an inspiration to seek new contexts and a point of departure for a new stance. ${ }^{25}$ In short, already in the first

24 However, the truth is that this theatre struggling for it very survival for many years (often without subsidies and grants) had to recall six plays from its repertoire in 2006 due to unclear copyright issues (on one occasion the theatre held a licence but failed to pay copyright fees, on another occasion it failed to get a permission to perform a play).

25 In this sense there is remarkable work by the amateur theatre Rádoby Klapý which has staged several titles composed in this way - the co-author of the script always being a prominent personality (L. Valeš, the principal and director of the company). At first glance, their titles will reveal no inspiration by Bergman. Under the name And the Infant Jesus Long Time Ago... they put up a peculiar play based on Bergman's film Fanny and Alexander (1999), the name Such a Strange Combination of Feelings concealed an adaptation of Autumn Sonata (2004). Under the name A Long Journey a play was created using motifs from Bergman's Wild Strawberries (2015). One can feel a great passion for Bergman's work in this theatre company. From time to 
decade of the new millennium a fundamentally different attitude to text by theatre began to show, affecting the sphere of Bergman's works along the way. This is a very indulgent attitude not respecting the artist, not insisting on the letter of the script, freely combining texts of varied provenance and building as broad associations as possible. This boundless freedom has its negative aspects too. However, it facilitates an interesting flow of popular motifs. This is also the case in the latest piece staged by The Theatre on the Balustrade entitled Personae (2018) made up of individual acts from the Scenes from a Marriage, Autumn Sonata, Hour of the Wolf and Persona where Antonius Block appears in the Prologue, unidentified in any greater detail. He moves to some empty flat where he intends to play chess with a Man that we know nothing about. He reveals to him what the plague of these days is:

Love is the blackest of all plagues and if one could die of it, there would be some pleasure in that misery. But love usually passes, you almost always get over it. Love is as contagious as a cold. It eats away at your blood, strength, independence and morale if you have any. ${ }^{26}$

This scene could hardly take place on the sea shore although the unknown man could be Death. Those two are drinking cognac in an empty room. It seems that the postponement Antonius Block is so keen on serves no other purpose than to get involved in cruel love affairs with which they fill the time of their lives. Neither the unknown man nor Block return to the play. As stated in reviews this was a personal choice made by the director who had transformed scenes from Bergman's films into a dark and depressing mosaic of human relationships (MACHALICKÁ 2018) . Yes, we know that but is it really all there is?

\section{Bibliography}

AMALVI, Christian. 2002. Middle Ages. In Jacques Le Goff and Jean-Claude Schmitt. Encyclopaedia of the Middle Ages. Prague: Vyšehrad 2002: 741-753.

BALCÁRKOVÁ Eva. 2007. Bušeni do železné opony. [Pounding on the Iron Curtain.] Master's thesis. Olomouc, Faculty of Arts, Palacký University, 2007. Available online at: https://theses.cz/ id/n4ijpq/Bušení do železné opony.pdf

time small amateur groups also turn to Bergman's work which is difficult in regard to its interpretation where one would not expect it: in 2012 the Sumus company performed with great success an adaption of the film Winter Light, amateur theatre group ÚD (Únione Dramático) made up of employees from the health sphere put on an adaptation of Scenes from a Marriage (2014) earning success at a number of theatre festivals. (For more information see http://www.amaterskedivadlo.cz/.)

26 From the text of the play. Many thanks to Dora Viceníková for making this play accessible. Authors I. Bergman, J. Mikulášek. Director: J. Mikulášek, dramaturgy: D. Viceníková, scenography and costumes: M. Cpin. Premiered at The Theatre on the Balustrade on $6^{\text {th }}$ and $9^{\text {th }}$ December 2018. The production was later cancelled due to the copyright issues. 
BERGMAN, Ingmar. 1982. Filmové povidky [Film Stories]. Transl. Z. Černík, D. Hartlová and J. Osvald. Prague: Odeon, 1982.

BERGMAN, Ingmar. 1991 Laterna magica. Czech translation by Z. Černík. Prague: Odeon, 1991.

CIESLAR, Jiří. 1982. Silence, Whispers and Shouts of Ingmar Bergman. In Ingmar Bergman. Filmové povidky [Film Stories]. Prague: Odeon, 1982: 400-416.

ČERNÍK, Zbyněk. 2013. Hra v šachy se Zubatou [Playing Chess with Death]. Divadelni noviny. 22:5 (5. 3. 2013): 4.

DONNER, Jörn. 1965 Djävulens ansikte. Stockholm: Albert Bonniers, 1965. Quote by OLIVA 1966: 155.

HUTCHEON, Linda 2010. What happens During Adaptation. Iluminace (2010): 1: 23-59.

KALIN, Jesse. 2007. Ingmar Bergman and his Films. Czech translation by M. Knápková. Prague: Casablanca, 2007.

KRYŠTOFOVÁ, Petra. 2009. Seven and a Half Theatre. Master's thesis. Brno, Faculty of Arts, Masaryk University. Available online at https://is.muni.cz/th/rt89w/.

MALÁ - HORÁKOVÁ, Zuzana. 2018. Private email correspondence, personal archive.

MACHALICKÁ, Jana. 2018. Persony v Divadle Na zábradlí. Osobní průvodce Ingmarem Bergmanem. Lidové noviny (15. 12. 2018). Available online at https:/ / www.lidovky.cz/kultura/recenze-personyv-divadle-na-zabradli-osobni-pruvodce-ingmarem-bergmanem.A181214_103409_ln_kultura_jto.

OLIVA, Ljubomír. 1966. Ingmar Bergman. Prague: Orbis, 1966.

STEENE, Brigitta. 2005 Ingmar Bergman. A reference guide. Amsterdam: University Press, 2005.

VEDRAL, Jan. 2012. Filmový mor na jevištích. Divadelni noviny 21:8 (17. 4. 2012): 12.

\section{prof. Eva Stehlíková}

professor emeritus of Masaryk University

Czech Republic

stehlikova@mail.muni.cz

The field of her scholarly interests include Classical Greek and Roman Theatre (The Greek Theatre of the Classical Period 1991, Roman Theatre 1993, Ancient Theatre 2005, in English Ancient Greek and Roman Theatre 2014, The theatre in the time of Nero and Seneca 2006), early medieval Theatre (And what if it is theatre? 1998), the theatre of the nineteen sixties (ed. Alfréd Radok between film and theatre 2007), modern productions of Classical drama in her country (What's Hecuba to us 2012). She translates from Classical languages (Menandros, Plautus, Seneca). 